\title{
Labor Migration of Ukrainians and its Importance for Development of Family Relations and Social Sphere of Ukraine
}

\section{J. Holonic (Jan Holonic)', K. V. Vasyliovych (Khymynets Volodymyr Vasyliovych)², T. G. Ivanivna (Tsimbolynets Ganna Ivanivna) ${ }^{3}$}

1 Doctor of Philosophy, Assistant at the Department of Social Work, Pedagogical Faculty, Comenius University, Bratislava, Slovakia.

2 Doctor of Economic Sciences, Professor at the Department of International Economic Relations of the State Higher Educational Institution "Uzhgorod National University", Ukraine.

3 Assistant at the Department of International Economic Relations of the State Higher Educational Institution "Uzhgorod National University”, Ukraine.

\section{E-mail address:}

holonic@fedu.uniba.sk

\section{Reprint address:}

Jan Holonic

Comenius University, Pedagogical faculty, department of social work,

Soltesovej 4

Bratislava

Slovakia

Source: Clinical Social Work and Health Intervention

Volume: 10

Issue: 3

Pages: $15-23$

Cited references: 12

\section{Reviewers:}

Andrea Shahum

University of North Carolina at Chapel Hill School of Medicine, USA

Roberto Cauda

Institute of Infectious Diseases, Catholic University of the Sacred Heart, Rome, IT

\section{Keywords:}

Migration. Employment. Development of Family. Citizen.

\section{Publisher:}

International Society of Applied Preventive Medicine i-gap

CSWHI 2019; 10(2): 15 - 23; DOI: 10.22359/cswhi_10_3_05 Published: October 2019 


\section{Abstract}

This article discusses the essence and the present state of migration in Ukraine. It investigates the migration trends in Ukraine and analyzes the destinations and age groups of Ukrainian labor migrants. The imperfection of a domestic statistical base and consequence of increased scales of international labor migration is parsed. The main socio-economic causes of labor migration and their consequences for the economy of Ukraine are revealed. The article also analyzes the main outcomes of migration of one of the family members for marital relations and relations between parents and children, considers the problems of social orphanhood or the so-called "euro orphanhood " as well as problems of care for the elderly as a consequence of the departure of children abroad. The economic substantiation of the influence of the outflow of labor resources on the sphere of social security, the state and peculiarities of functioning of Ukrainian Medical Institutions is provided.

The peculiarity of the development of the world economy in the $21 \mathrm{st}$ century is its globalization, which manifests in the free flow of capital, material and labor resources. The globalization of production; the strengthening of the interdependence of national economies; as well as, as a consequence, the emergence and continual development of the international labor market that covers the flows of labor resources crossing the national borders lead to labor migration of Ukrainian citizens.

The attempt to develop the economy in Ukraine did not lead to a solution to the problem of real improvement of living conditions of the population and the growth of demand for labor. Most indicators of socio-economic development indicate an increasing impoverishment of the Ukrainian people. The employment opportunities in Ukraine's formal labor market are insignificant, and, in addition, employment in the state sector does not guarantee prosperity and does not meet the needs of the reproduction of the workforce of the worker.

\section{Objective}

The objective of the article is to study the state of external migration processes in Ukraine; analysis of factors; determination of factors of external labor migration of the population; their consequences for the social sphere and family relations in Ukraine.

Design. The article consists of considering the following issues: 1. The main tendencies of labor migration in Ukraine. 2. The reasons for the employment of Ukrainians abroad, their positive and negative consequences. 3. The impact of labor migration on marital relations, as well as the relationship between parents and children. 4. Consequences of increasing the scale of labor migration for the state of the social sphere and social security of the country. 5. Problems of elderly care as a consequence of the departure of children abroad.

Participants: labor migrants from Ukraine, especially the category which have families and children. 
Methods of research: for the development of this scientific work we used methods of the system approach, system, economic and statistical analysis and comparison. Much of the information provided by the article was obtained through numerous sociological surveys of labor migrants, as well as the observation of separate groups of families in which there are labor migrants. Currently, Ukraine is one of the largest provider countries of labor resources in Europe and is among the top ten donor countries. The development of external migration processes in Ukraine is associated with low wages in all sectors of the economy, an increase in compulsory part-time employment and unemployment, as well as the spread of poverty and a high level of property segregation of the population [1, p.35-39]. The main causes of international labor migration from Ukraine are:

- search for sources of improvement of the economic situation by raising wages and additional income;

- insufficient number of jobs in the country;

- search for a better life and working conditions abroad

- search for the greatest and best opportunities in the social sphere, especially in medicine, education, pensions, and the like;

- lack of prospects for professional development and career growth;

- instability of the political and economic situation in the country;

- unfavorable conditions for doing business and widespread corruption in all spheres of social, political and economic life

All the reasons presented lead to an increase in the processes of external labor migration from Ukraine, especially with regard to young qualified personnel [2, p. 148-152]

According to the Center for Economic
Strategy, the total number of the Ukrainian population who participated in labor migration in the period from 2015 to 2017 is 4 million people. (That is, about $16 \%$ of the working population).

The general trend of Ukrainian migration is now its "circular" nature: citizens leave, earn money abroad and return to spend them at home. Therefore, at the same time, not all labor migrants are abroad, but about 2.6-2.7 million people.

We can specify which countries are the most common among labor migration from Ukraine: Poland - 40.76\%, Russian Federation - $17.81 \%$, Hungary - 10.45\%, Moldova $-7.41 \%$, Belarus $-5.95 \%$ Slovakia - 3.23\%, Romania - 2.94\%, Turkey - 2.31\%, Egypt - 1.51\%, Germany - 1.26\%, United Arab Emirates - $0.59 \%$, Israel - 0.56\%, Italy $0.5 \%$, Austria $-0.46 \%$, Greece $-0.44 \%$, other countries $-3.84 \%$. According to the age category of labor migrants, this phenomenon is typical for people of more mature age - about $71 \%$ of all labor migrants aged 1844 years, an average of 34 years. Labor migration from Ukraine is also characterized as a long-term phenomenon, since the majority of migrants leave Ukraine for a considerable period of time [3].

The negative consequences of labor migration include: depopulation of the country's total population; deterioration in the quality of upbringing of children in families of migrant workers (social orphanhood or the problem of another lost generation); disintegration of families; the outflow of the best labor potential of Ukraine; crime and corruption; political aspects; migrant workers are mainly employed in jobs that do little to improve their skills or acquire the skills necessary for future productive activities in their homeland. The positive effects of labor migration include: increasing the solvency 
of families of migrant workers; promoting the formation of a middle class in Ukraine; receipt of additional funds in the budget of Ukraine; reducing the burden on the labor market; prolonged stay in developed countries contributes to the formation of the experience of modern economic management; market consciousness; the assimilation of values and norms of a civilized society among labor migrants[4, p.23].

In our article, we will look at precisely the negative impact of migration on the social sphere and family relations, which has already become an essential attribute of labor migration. The majority of labor migrants have from one to three children, children remain for one of the parents, for the older generation, neighbors, or simply for themselves. As a result of a long break in family ties, very often the antisocial behavior of a parent left with the children leads to alcoholism, debauchery, domestic violence (including sexual violence), and eventually to the actual cessation of the existence of a family that was considered to be the foundation of the security of the nation and the state.

Labor migration expands opportunities for professional realization and career growth, contributes to increasing incomes and, accordingly, improving family welfare. However, these material achievements provoke a narrowing; transformation of its other functions the implementation of which is much more complicated. Unique social and psychological functions of the family; psychological support and mutual assistance; the removal of emotional stress; the realization of most individual needs cannot be fully carried out at a distance through communication tools; in conditions of intensification of social processes the acceleration of the rhythm of life are especially important. Such functions as mutual social control, social protection are not fully implemented. Under the conditions of demographic aging; the importance of the functions of caring for and caring for elderly family members who need instrumental assistance increases; their implementation is questionable. The main, most important functions of the family, which are necessary at all stages of the development of society, are the subdivision, socialization and the material maintenance of children. External migration, as a rule, improves the conditions for the material maintenance of children, however, there is a significant risk of underperformance and deformation of the reproductive and educational function. There is a risk of not giving birth in the case of a long-term absence of one of the spouses; deterioration due to this relationship; their instability; emotional alienation; misunderstanding and the like. Especially negative impact is a long separation of parents and children, because "fatherhood at a distance" which is sometimes defined as transnational paternity/motherhood, changing forms of interaction between parents and children give rise to a whole complex of psychological, pedagogical, emotional problems, and is a significant risk of full socialization' of the child.

Modern means of communication create opportunities for new forms of communication, education, care for parents and children, but this only partially compensates for the lack of direct, live communication. So, a transnational family, on the one hand, testifies to the deformation and even destruction of traditional forms of family ties; lack of fulfillment of a number of important functions; on the other hand, indicates the adaptive capabilities of the family institution; its ability to adapt to new social processes transforming forms of family ties. The family institute, being quite stable, has a certain flexibility, the ability to adapt to new conditions [5, p. 50-56]. 
In the conditions of mass labor migration in modern Ukraine, transnational families are becoming more common. The positive impact of the work of one family member abroad is the undoubted improvement of the material condition of the family: in the conditions of poverty of a large part of Ukrainian families, primarily families with children, the receipt of funds from a migrant worker allows the solving of some economic problems, including ensuring decent material conditions of keeping children. According to the results of the modular sample survey on labor migration conducted by State Statistics in January-June 2017, 45\% of households received material assistance from abroad, assessed their level of welfare as below average, and $43.8 \%$ considered themselves to the poor and the very poor. So the receipt of funds (\$1100-1500) is a significant material support. The majority of households receiving assistance from abroad, receive it from one of the spouses (husband or wife), adult children and even other relatives, is a definite evidence of the preservation of the traditional Ukrainian family solidarity, mutual help of generations in a new, "distance" form. The family "delegates" one of its members to solve their economic problems (housing, education, treatment, formation of insurance savings), including to improve the living conditions of children. The main motive of labor migration is to improve the quality of life of the family, especially for children investment in their education. However, solving economic issues at the same time such a family carries numerous problems and risks - by marriage, the socialization of children, the loneliness of the elderly. One of the most acute problems of the Ukrainian family for a long time is the instability of marriages and the high level of divorce. According to several selective surveys, more than half of labor migrants are married both among those whose emigration is short-term (up to twelve months) and among those who have been abroad for a long time. The prolonged absence of one of the spouses in one form or another necessarily affects a relationship contributing to alienation, misunderstanding and reduction of common interests.

If one of the parents works abroad, the children are brought up in single-parent families, the specifics and risks of which are well known. However, if both parents are absent, or a labor emigrant is a mother who raises a child herself (the proportion of divorced and widowed women is high among such women: according to the last selective survey, every third woman), then socialization of children occurs in extremely unfavorable, distorted conditions. Such children are sometimes called "euro orphans" or "children left behind." These children need special pedagogical and psychological approaches as they are emotionally vulnerable and have a significantly higher level of anxiety compared to children from complete families [6, p. 98-103].

External labor migration is one of the factors that significantly increases the risk of loneliness

of the elderly. The problem of loneliness of the elderly is one of the challenges of our time; in the conditions of increasing aging of the population it is exacerbated in all countries. In modern Ukraine, according to sample polls, the overwhelming majority of the elderly (men and women) sometimes or permanently need help in doing household chores, and this need increases with age because for health reasons, the ability to self-service and homework is reduced. The problem is exacerbated by significant gender differences in mortality, average life expectancy and gender characteristics of marriage behavior. Older women living alone in the household are primarily at risk of neglect and lack of help. The traditions of 
family mutual help between the generations in the country are quite strong: the majority of the elderly receive help and care from their adult children, grandchildren, or other relatives, if necessary, and receive material assistance, including from children of migrant workers. However, the possibilities of instrumental support, care depend on the form of residence, the distance between relatives, and labor migration allows increasing financial assistance to elderly parents, however, it changes forms, sometimes limits communication, and makes direct care and care impossible [7, p. 113-117].

In the human rights context at the international level, priority is given to the reunification of migrant families, primarily parents and children, in the host country. It is important for Ukraine that this reunion takes place at home, in our country. A number of researchers include children of migrant workers in the category of social orphans, but in our opinion, a more flexible, targeted approach is needed in this issue: how long parents are absent; how they maintain contact with their child; the family in which the child is at the time of their absence; the conditions of her maintenance and upbringing - that is, to come not from the status of the child, but from the real conditions of his life. However, one should understand that only creation of comfortable conditions for life and education of children in Ukraine - safety, ecology, quality of social infrastructure, etc. - will be a powerful argument for parents in solving the issue: to return children to their homeland or take them abroad to the country of their employment. The process of demographic aging affects practically all spheres of society's life both at the level of individuals and households as well as of the population as a whole. Due to the natural and migratory contraction of the number of young people, Ukrainian society is losing its potential for development. On the other hand, the growth of the proportion of older people in the structure of the population causes an increase in demand for appropriate types of support; services provision for the elderly; pensions; medical services. There is a shift in social spending towards passive support for older people and an appropriate reorientation of social policies. According to estimations, based on national social security accounts, the total expenditures that are sent to support elderly people in Ukraine already account for about $65 \%$ of the total expenditures on social protection of the population. And on the basis of existing demographic trends, these costs will continue to rise, creating significant pressure on society $[8$, p.203-206].

Changes in the age structure of the Ukrainian population are due to natural demographic aging (mainly due to low birth rates, which has been observed for quite some time), as well as to the significant scale of migratory losses of the active population, including through labor migration. As a result, the burden on pensioners on the working-age population is even greater, and the ratio between the number of contributors and the number of pensioners deteriorates. Now in the pension system of Ukraine there are $11,700,000$ pensioners and only $12,800,000$ payers of contributions, that is, 100 pensioners account for 91 pensioners. Based on current trends, in the middle of the century this ratio could reach almost 120 pensioners per 100 payers. The social consequences of this may be the spread of poverty among retirees, social rejection of the elderly, and the deepening of the conflict between the generations.

Unfortunately, neither economic nor demographic forecasts indicate prospects for improving the situation. As a result, the burden on pensioners on the working-age 
population is even greater, and the ratio between the number of contributors and the number of pensioners deteriorates [9].

In addition to the problem of pensions, the growth in demand for services for the elderly is equally important. The Ministry of Health states: every fifth person of elderly people is over 60 years old and lives lonely; every tenth cannot serve himself; $5-6 \%$ of pensioners are chained to lust. According to the State Statistics Service, at the beginning of 2017, 1,200,000 senior citizens were identified to be in difficult life circumstances and needed social services: more than 400,000 needed social services at home; 360,000 in social adaptation departments; almost 100,000 - in social and medical services; 9,000 - in stationary departments for permanent or temporary residence. About 300,000 senior citizens require the provision of targeted monetary and in-kind supplementation. Ukraine has an extensive network of social service institutions for senior citizens which provide a range of social services covering all major aspects of the life of an elderly person. In the end of 2016, 65 residential homes for elderly and persons with disabilities functioned in Ukraine; 27 resorts for war and labor veterans; 3 special residential homes; 664 territorial centers for social services (social services) in which there were 2,465 departments. According to Ukrainian League for the Development of Palliative and Hospice Aid, in 2016, there were 7 hospices in Ukraine, two centers and 60 independent departments of palliative care. Most of these institutions are public. In addition, according to the Ministry of Health, in 2015, the country had 25 budget year-round resorts for adults of the MOZ344 structure.

At the same time, the problem of the functioning of this network is quite complex, since it concerns the satisfaction of the diverse specific needs of the elderly. Recent studies have identified an insufficient number of certain types of social service institutions for senior citizens in the country. Thus, according to estimates made on the basis of the survey "Older men and women in Ukraine: living conditions and social well-being", the needs of the elderly in social services are not satisfied by $20.5 \%$. The question of the adequacy of social welfare institutions for the elderly in rural areas remains difficult. As a rule, social services and territorial centers of social services are located in regional centers and serve villages and small towns of the district center. In villages and small towns such institutions are often absent. At the same time, the distance between settlements can be quite significant, and in combination with the inadequate development of transport infrastructure, situations arise in which it is difficult for social workers to reach the recipient in order to provide relevant services.

An extremely acute problem in Ukraine is the lack of hospices and palliative care units for seriously ill and elderly people. There is a big gap between the need for hospice beds and their actual number. According to the calculations of international experts, the need for hospice beds is 4-5 times higher, and an even greater number of patients in the terminal stage of the disease need hospice care at home. In this regard, there is a need for government support for the poor elderly people with limited physical ability and insufficient financial resources. As a rule, the problem lies not only in the financing of such services, but also in the provision of nursing staff. Although there are no official statistics on foreign labor migration in the specialty (an assessment of their number requires special study), a certain part of Ukrainian doctors and nurses currently work in other countries on a permanent or temporary basis. On the 
other hand, the facilitation (due to the visa-free regime) of internship opportunities or study abroad, the higher mobility of medical workers (provided they are set to return to Ukraine) is a powerful factor in human development [10].

\section{Conclusion}

In order to minimize negative influence of external migration on the Ukrainian family, primarily on children, it is necessary that educational institutions, social services take into account the specifics of the families of migrants in their activities, provide timely pedagogical and psychological assistance, acted in close cooperation with local communities and non-governmental organizations. According to experts, this particular group of children should definitely be included in the target group for psychologists and social workers. The specifics of the current socio-economic situation in the country necessitate the search for answers to the social, financial and economic challenges of population aging, as well as the concentration of efforts to support the most vulnerable groups of the population. The policy of long-term care under such conditions should be combined: along with the development of alternative forms of in-patient care, measures should be introduced to support family forms of care (including foster families) and volunteer activities. But it should be understood that solving the problems of social support of the elderly and counteracting their social isolation lies not only in the plane of passive support, but also depends on how successful the policy of maintaining active longevity, the activation of persons of older age groups, creation of conditions for the full use of their capacity in various spheres of life-affairs. I also need to overestimate the role of the older generation in society. We must move from perceiving these people as inactive and dependent on the formation of the image of active participants in social development.

\section{References}

1. KHOMUMENKO L I (2016) Migration Trends in Ukraine: Peculiarities of Ukrainian Labor Migration / L.I. Khomumentenko, AP Grebenyuk // Market Infrastructure. - Issue 2, p.35-39.

2. SMUTCHAK Z V (2017) Socio-economic consequences of the intensity of external labor migratory flows / Z.V. Smutchak // Scientific Bulletin of Uzhgorod National University. Series: International Economic Relations and World Economy. - - Voip. 11. - P. 148-152.

3. UKRAINE'S MIGRATION PROFILE FOR 2017 [Electronic Resource]//State Migration Service of Ukraine. - 2018 - Resource access mode: https://dmsu.gov.ua/assets/files/mig_profil/migprofil_2017.pdf

4. KALININA S P (2015) Transformation of the international labor market in the context of globalization shifts / SP Kalinina, Yu.O. Getmanenko, O.S. Gaidash; for community edit Dr. Econ. Sciences, Prof. S.P. Kalinin Vinnitsa: LLC “Nilan-LTD”. - 240s.

5. KOVYAZIN C S (2013) Social protection of children of migrant workers: conceptual foundations and state policy [Text] / K. O. Kovyazin // Strategic priorities. No. 4. - P. 50-56.

6. MUSS C, BENCA G, NADDOUR A, KRCMERY V, SRAMEKOVA M, SIMONEK T, JACKULIKOVA M, DRGOVA J, MATULNIKOVA L, KOVAC R, POLONOVA J, PROCHAZKOVA C, KOVAC M, OLAH M, BELOVICOVA M, BARTOSOVIC I, ZOLLER C (2018) Migrants Versus Homeless Population in Rehabilitation and Physiotherapy Facilities Suffering from Ectoparasites - Scabies is not a Medical but Social Problem. In Clinical Social Work and Health Intervention. Vienna: GAP, 2018. 
No. 3. Vol. 9. 67 - 70 p. DOI 10.22359/ cswhi_9_3_09. ISSN 2222-386X.

7. SKALETSKY M (2013) Labor migration and the problem of social orphanhood in Ukraine [Text] / Mikhail Skaletsky, Oksana Ostrochuk // Bulletin of the National University "Lviv Polytechnic". Series: Philosophical sciences: / Ministry of Education and Science of Ukraine, National Academy of Sciences of Ukraine. University Lviv Polytechnic University; [rare: VL Petrushenko (ed.), etc.]; rep. edit V. L. Petrushenko. Lviv: Lviv. Polytechnic, 2013. P. 98-103.

8. TERESHCHENKO I I (2011) Peculiarities social work with people in the age of learning in the learning of ukraine / Tereschenko I. I., Naumez AM // Bulletin of NTUU "KPI". Politology. Sociology. Law: a collection of scientific works. No. 3 (11). - P. 113-117.

9. KOVAC R, POLONOVA J, PROCHAZKOVA K, MIKOLASOVA C, KRCMERY V, BERNADIC M, KISAC P, KALAVSKY E, MRAZOVA M, MATEICKA F, LISKOVA
A, MAMOVA A, OLAH M, HERDICS C, IBRAHIM M (2018) Absence of TB and HIV in sheltered homeless population of Bratislava (Slovakia) In Medical Horizon. Vol 67, No 6, pp 202-203. ISSN 04574214.

10. SOPKO R (2013) Problems of care for the elderly. Palliative and Hospice Assistance in Ukraine / R. Sopko // Scientific Bulletin of Uzhgorod National University. Series: Pedagogy. Social Work. Issue 29. - P. 203206.

11. HOMEMADE CARE IN UKRAINE: how and for whom social care for loners is provided? [Electronic resource] // GLAVKOM. - 2017. - Resource access mode: https:// glavcom.ua/specprojects/press_center/domashnya-opika-v-ukrajini-yak-i-komunadajetsya-socialna-dopomoga-dlya-samotnih-441467.html.

12. NATIONAL REPORT [Electronic resource] // NATIONAL ACADEMY OF SCIENCES OF UKRAINE - Mode of access to the resource: http://www.nas.gov.ua/UA/Pages/ default.aspx. 